\title{
Continuous acoustic studies of overwintering sprat Sprattus sprattus reveal flexible behavior
}

\author{
Ingrid Solberg ${ }^{1, *}$, Thor A. Klevjer ${ }^{1}$, Stein Kaartvedt ${ }^{1,2}$ \\ ${ }^{1}$ Red Sea Research Center, King Abdullah University of Science and Technology, Thuwal 23955-6900, Saudi Arabia \\ ${ }^{2}$ University of Oslo, Department of Biology, PO Box 1066 Blindern, 0316 Oslo, Norway
}

\begin{abstract}
The clupeid fish Sprattus sprattus was studied in a $150 \mathrm{~m}$ deep Norwegian fjord throughout an entire overwintering period during which the fjord froze over and a major water renewal occurred. A bottom-mounted (upward-facing) echosounder provided continuous highresolution data and enabled studies of swimming speed and behavior of individual sprat in addition to population behavior. The continuous acoustic studies were supplemented with intermittent field campaigns. The sprat displayed different behavioral modes with changing environmental conditions. During the first part of the winter, the majority of the population occurred in deep waters during both day and night, yet exhibited a shallower night-time distribution. Individual sprat swam alternately up and down, a 'rise and sink' behavior likely a compensation for negative buoyancy because of swim bladder compression. Because feeding was negligible in deep waters, the swimming pattern was not inferred as prey search behavior. Another part of the population schooled at shallower depths during the day and carried out vertical migration to upper waters at night. However, individuals were observed as they switched between these behavioral groups. A sudden change in both swimming behavior and vertical distribution occurred as the fjord became ice covered. Near-bottom 'rise and sink' swimming was replaced by schooling in midwater during the day, and the sprat aggregated in dense layers near the surface at night. We suggest that the ice made the sprat shift their antipredator strategy from hiding at depth to hiding in schools in the darker waters below the ice. This long-term acoustic study has shown that sprat have a flexible behavioral repertoire, displaying different overwintering strategies within a population, depending on environmental conditions.
\end{abstract}

KEY WORDS: Sprat · Overwintering · 'Rise and sink' swimming · Schooling · Ice cover

\section{INTRODUCTION}

Winter may represent a crucial period in the life history of fishes (Simpson 1953, Hoag 2003), and overwintering ecology is important in fisheries science, such as in habitat management and habitat evaluation, and regarding impacts of climate change (Hurst 2007). Research of overwintering environments has increased during the last 2 decades, and the habitat and behavior of a large number of freshwater fish have been investigated (Riehle \& Griffith 1993, Kynard et al. 2000, Huusko et al. 2007). How- ever, the overwintering microhabitats of marine and estuarine fishes are mainly unknown.

The clupeid sprat Sprattus sprattus is a widely distributed and commercially exploited fish in coastal environments (Harvey et al. 2003, Casini et al. 2006). Sprat commonly occur in habitats characterized by hypoxia in deep waters such as the Baltic and Black Seas and some fjords (Daskalov 2003, Kaartvedt et al. 2009, Stepputtis et al. 2011). Kaartvedt et al. (2009) suggested that overwintering sprat might exploit low oxygen waters as a refuge because they have a higher tolerance for low-oxygen waters than their predators. 
Populations of sprat are also present in environments that may be covered with ice, e.g. the Baltic Sea and some Norwegian fjords (Ojaveer \& Kalejs 2005, Casini et al. 2006, Kaartvedt et al. 2009). Ice will affect not only light conditions, but also the ability for this physostome fish to ascend to the surface for gulping air in order to fill its swimbladder (Blaxter $\&$ Batty 1984). There are, however, no studies on how ice covering may affect the overwintering sprat.

The inner part of the Oslofjord is easily accessible for long-term acoustic measurements. In the present study we took advantage of this to continuously monitor a population of sprat throughout a whole overwintering period. We deployed an echosounder, cabled to shore, at the bottom of the fjord during a winter where waters were hypoxic, yet sufficiently oxygenated for the sprat to inhabit the whole water column. Because the echosounder was situated at the bottom, it provided high-resolution data of acoustic targets in deep waters, enabling studies of swimming behavior of individual sprat near the bottom. As it was connected to shore, it provided continuous measurements with no limitation of power or storage capacity of data. In this way, we were able to assess individual behavior at a temporal resolution of $\sim 1$ data record $\mathrm{s}^{-1}$ throughout the winter. This approach also allowed us to observe how the overwintering sprat were affected as the fjord became covered with ice, and how they responded to the influx of new and more oxygenated waters.

\section{MATERIALS AND METHODS}

\section{Study site and environmental conditions}

The study took place in Bunnefjorden (150 m deep) from November 2005 to April 2006. Bunnefjorden is the innermost part of the Oslofjord, oriented as a parallel branch to the main fjord axis (Fig. 1 in Klevjer \& Kaartvedt 2011). This fjord branch is normally characterized by low-oxygen concentrations in the deep waters. There are 2 sills that restrict deep water exchange, one $(19 \mathrm{~m})$ is located in the narrow sound that connects the Oslofjord to outer waters, and the other $(\sim 50 \mathrm{~m})$ is situated at the inlet to Bunnefjorden (Klevjer \& Kaartvedt 2011). Nevertheless, there is normally a water renewal every 2 to $3 \mathrm{yr}$, resulting in periods with well-oxygenated water in the whole water column.

The hydrography of the 2005 to 2006 winter is described in Klevjer \& Kaartvedt (2011), who addressed the behavior of krill. In short, the salinity and temper- ature in the lower part of the water column were approximately 33 and $7.5^{\circ} \mathrm{C}$, respectively, with slightly warmer and fresher waters above. An abrupt increase in temperature $\left(\sim 1^{\circ} \mathrm{C}\right)$ occurred on 19 February 2006 (recorded from continuous measurements from a bottom-mounted conductivity-temperaturedepth (CTD) probe, reflecting an influx of new water. This water renewal brought more oxygenated water into the fjord basin. The oxygen content in bottom waters was $<2 \mathrm{ml} \mathrm{O}_{2} \mathrm{l}^{-1}$ at the beginning of the winter and $>4 \mathrm{ml} \mathrm{O}_{2} \mathrm{l}^{-1}$ by the end of the study (Klevjer \& Kaartvedt 2011), i.e. below $30 \%$ saturation and above $60 \%$ saturation, respectively.

A web camera was used to monitor the ice conditions of the fjord (images every hour from 4 February 2006). The fjord became ice covered the morning of 6 February 2006. There was a patchy distribution of ice until the evening of 8 February 2006, and thereafter the fjord remained completely ice covered until 14 April 2006.

\section{Sampling}

Sampling campaigns were carried out using the research vessel of the University of Oslo, RV 'Trygve Braarud'. Pelagic trawling was conducted day and night (43 pelagic hauls in total). The trawl has an aperture of approximately $100 \mathrm{~m}^{2}$ and was towed at 2 knots. The mesh size is $20 \mathrm{~cm}$ near the opening, declining to $3 \mathrm{~mm}$ in the cod end. Trawling depths were selected based on acoustic scattering layers recorded by echosounders onboard the vessel (Simrad EK500, 120 and $38 \mathrm{kHz}$ ). A Scanmar depth sensor measured the trawling depth during each sampling. The trawl was equipped with a multisampler cod end (Engås et al. 1997), enabling vertically stratified sampling. All fishes were identified to species and counted, and the volume of krill in each haul was noted. Subsamples of 30 sprat when available were analyzed for stomach contents and measured for total length. The length distributions of different depth intervals were compared statistically with ANOVA followed by a post hoc Tukey's test.

For presentation of the trawl results, the water column was divided into three $50 \mathrm{~m}$ intervals and results from all hauls from within each of these intervals were averaged. The results were standardized as the number of sprat per $10 \mathrm{~min}$ of trawling. Two additional bottom trawls were conducted during the daytime for 30 min in December. The bottom trawl has a smaller aperture and a coarser mesh size; therefore the results from the 2 nets are not compared quantitatively. 


\section{Acoustic studies}

A mooring with an upward-facing bottom-mounted Simrad EK60 echosounder (120 kHz ES120-7) was deployed at $150 \mathrm{~m}$ depth $\left(59.792171^{\circ} \mathrm{N}, 10.726776^{\circ} \mathrm{E}\right)$, as described in Klevjer \& Kaartvedt (2011). The submerged acoustic transceiver was connected to land with a cable that provided electricity and transmitted digitized signals to a laptop computer on shore. The temporal resolution of data (ping rate) was 1 to 2 pings $\mathrm{s}^{-1}$, and the pulse length was $0.256 \mathrm{~ms}$. The echosounder was deployed on 24 November 2005 and retrieved 20 April 2006. Calibration by the standard sphere method (Simmonds \& MacLennan 2005) was carried out both prior to deployment and immediately after retrieval of the acoustic rig. The calibration results were significantly different from each other, giving weaker echoes at the end of winter, indicating that performance of the transducer changed throughout the study period. Data on target strength (TS, a measure for target size; Simmonds \& MacLennan 2005) were therefore only used in comparison with trawl catches in assessing and identifying acoustic targets. The drift in the mean volume backscattering strength $\left(S_{\mathrm{v}}\right)$ was $<2 \mathrm{~dB}$, which will not affect the conclusions on abundance presented here.

\section{Acoustic postprocessing}

Individual swimming behavior was assessed by target tracking (TT) using the acoustic software program Sonar 5 Pro (Balk \& Lindem 2005). TT combines single echoes recognized by the pulse-length-based single echo detector (SED) of Sonar 5 into tracks, and in automatic TT, individual tracks are selected based on algorithms that utilize information on the proximity of sequential echoes (Balk \& Lindem 2005). Automatic TT was performed from 1 January to 8 February 2006. This period of tracking was selected because the number of ascending and descending tracks decreased by nearly an order of magnitude as the sprat changed their behavior after the fjord became ice covered in early February. Tracking was performed in the range of 5-70 $\mathrm{m}$ from the transducer. In order to accept a track, a minimum of 15 valid echoes were required, allowing only one missing echo. To be included in the track, subsequent echoes were required to be within 1 degree in the horizontal dimension and $20 \mathrm{~cm}$ in the vertical orientation. Settings with restrictions in vertical and horizontal dimensions were applied in order to reduce the number of tracks made out of multiple targets. Tracks with SEDs with a target strength higher than $-42 \mathrm{~dB}$ and lower than $-65 \mathrm{~dB}$ were excluded so that tracks from larger fish (such as whiting and cod) or the weaker acoustic records from krill were not included in the data. Only results on descending tracks are given here; because the sprat TS declined strongly when ascending, the automatic tracking thereby created a bias towards excluding steeply ascending individuals.

To assess the abundance of sprat during the day and at night, the $S_{\mathrm{v}}$ was determined by integration of acoustic data over the whole water column $(150 \mathrm{~m})$. Integration was made over $10 \mathrm{~m}$ depth intervals and 30 min periods from 1 December 2005 to 16 April 2006 at a threshold of $-65 \mathrm{~dB}$ (krill and smaller zooplankton were not visible at this level). As sprat completely dominated the acoustic backscattering at this threshold, all integrated backscatter was allocated to sprat. Results are presented as $S_{\mathrm{v}}$ values for each day, and weighted mean depth (WMD) was calculated for each day according to the equation:

$$
\mathrm{WMD}=\sum\left(s_{\mathrm{v}} d_{\mathrm{i}}\right) / \sum s_{\mathrm{vi}}
$$

where $S_{\mathrm{v}}$ and $d_{\mathrm{i}}$ are, respectively, the volume backscattering coefficient (linear values of $S_{\mathrm{v}}$ ) and its corresponding depth. Four days of the acoustic record in December were contaminated with noise from nonbiological sources; these days were therefore excluded from the integration results.

Statistical analyses of abundance and WMD were performed using the Mann-Whitney U-test implemented in the software R.

\section{RESULTS}

\section{Trawl catches}

Sprat dominated the trawl catches in the beginning of the winter (present in 29 of 32 hauls from November-January), whereas krill (Meganyctiphanes norvegica) (152 l caught in total) were the most abundant species in April. Among the total catch of 3617 sprat, only 4 were caught in April. The small catches of sprat in spring is in accordance with the acoustic registrations, which show a clear decrease of backscatter ascribed to sprat at the end of winter (see below).

The overall average catch rate (sprat per $10 \mathrm{~min}$ of trawling) day and night was $\sim 10$ in November, $~ 30$ in December and 80 in January. Although some sprat were collected in shallower waters at night, the 
majority were always caught below 100 m (Fig. 1). The 2 bottom trawls conducted during daytime in December (data not shown) contained a total of 1079 sprat. Catches of other species were scarce; see Klevjer \& Kaartvedt (2011) for details.

\section{Stomach contents and length distribution}

In total, $79 \%$ of the sprat stomachs were empty ( $\mathrm{n}=704$ ). Some feeding took place in the shallowest depth interval $(0-50 \mathrm{~m})$, where $43 \%$ of the stomachs contained remnants of prey organisms, mainly the copepods Calanus spp. and Acartia spp. From catches deeper than $50 \mathrm{~m}$, only $15 \%$ of the stomachs had prey contents $(\mathrm{n}=574)$.

The average size of sprat was largest in November, exceeding $12 \mathrm{~cm}$ in the daytime catches; the
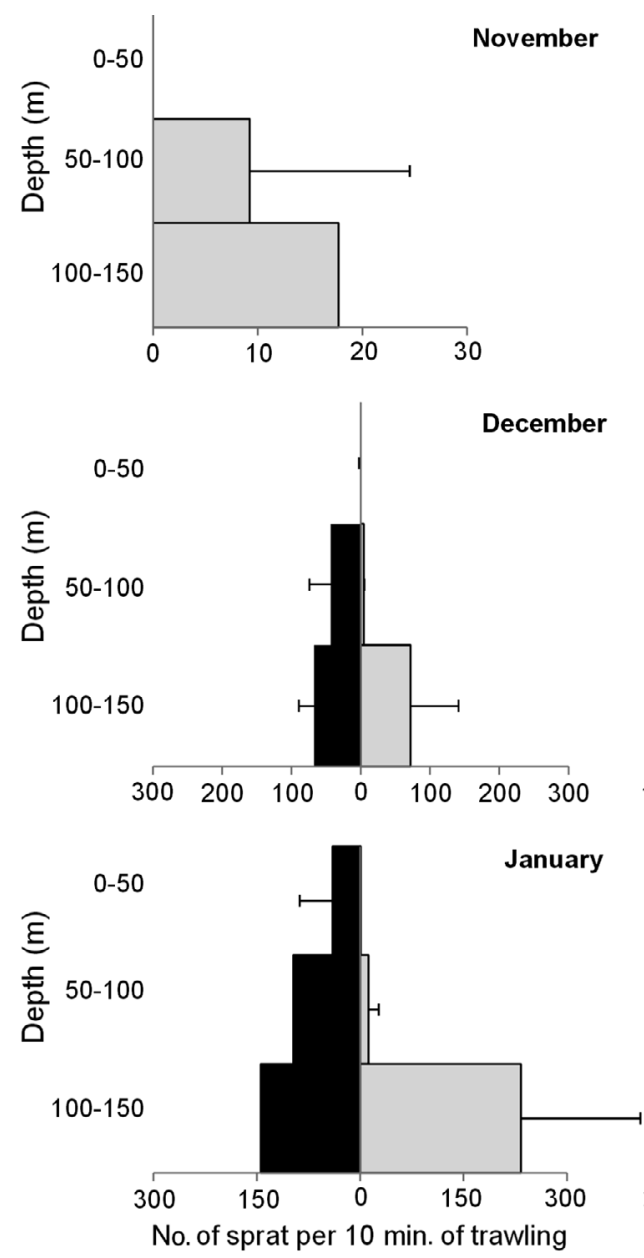

Fig. 1. Sprattus sprattus. Catches of sprat in Bunnefjorden from November to January presented as number of sprat per $10 \mathrm{~min}$ of trawling (left) and the subsequent length distributions (right), split into night (black) and day (grey) values. Error bars are standard deviations size distributions in December and January ranged from approximately 9 to $11 \mathrm{~cm}$ (Fig. 1). Absolute size differences by depth were small, yet the largest sizes were always caught in the deepest interval (Fig. 1) and the lengths were significantly different by depth (ANOVA, Tukey's test, $\mathrm{p}<0.01$ for all depth intervals).

\section{Acoustic studies}

\section{Abundance}

$S_{\mathrm{v}}$ of sprat gradually increased during December (Fig. 2). Daily averages for the last $7 \mathrm{~d}$ of December were significantly higher than for the first $7 \mathrm{~d}$ of the month (Mann-Whitney $U$-test, $\mathrm{p}<0.01, \mathrm{n}=14$, for both diurnal and nocturnal values), as the abundance of sprat in the overwintering habitat increased throughout the initial period. A marked drop in $S_{\mathrm{v}}$ values was initiated as the fjord became ice covered; the decline began some days earlier for day than for night (Fig. 2). Night-time $S_{\mathrm{v}}$ values thereafter declined from approximately -78 to $-87 \mathrm{~dB}$ in the period from mid February until March (Fig. 2), suggesting a near 10-fold reduction in biomass (second week of February versus the third week of March, Mann-Whitney $U$-test, $\mathrm{p}<<0.01, \mathrm{n}=$ 14). The backscatter subsequently declined rapidly in April.

\section{Behavior}

The sprat changed both vertical distribution and behavior throughout the winter (see summary in Table 1). During the first part of the winter, the majority of the sprat population inhabited near-bottom waters with an oxygen saturation of $\sim 30 \%$. They were swimming with a continuous 'rise and sink' behavior close to the bottom (below $120 \mathrm{~m}$ depth) during the day (Fig. 3). This deep portion of the population carried out diel vertical migration (DVM), but did not migrate all the way to upper layers at night (Fig. 4A). At dusk, the sprat 

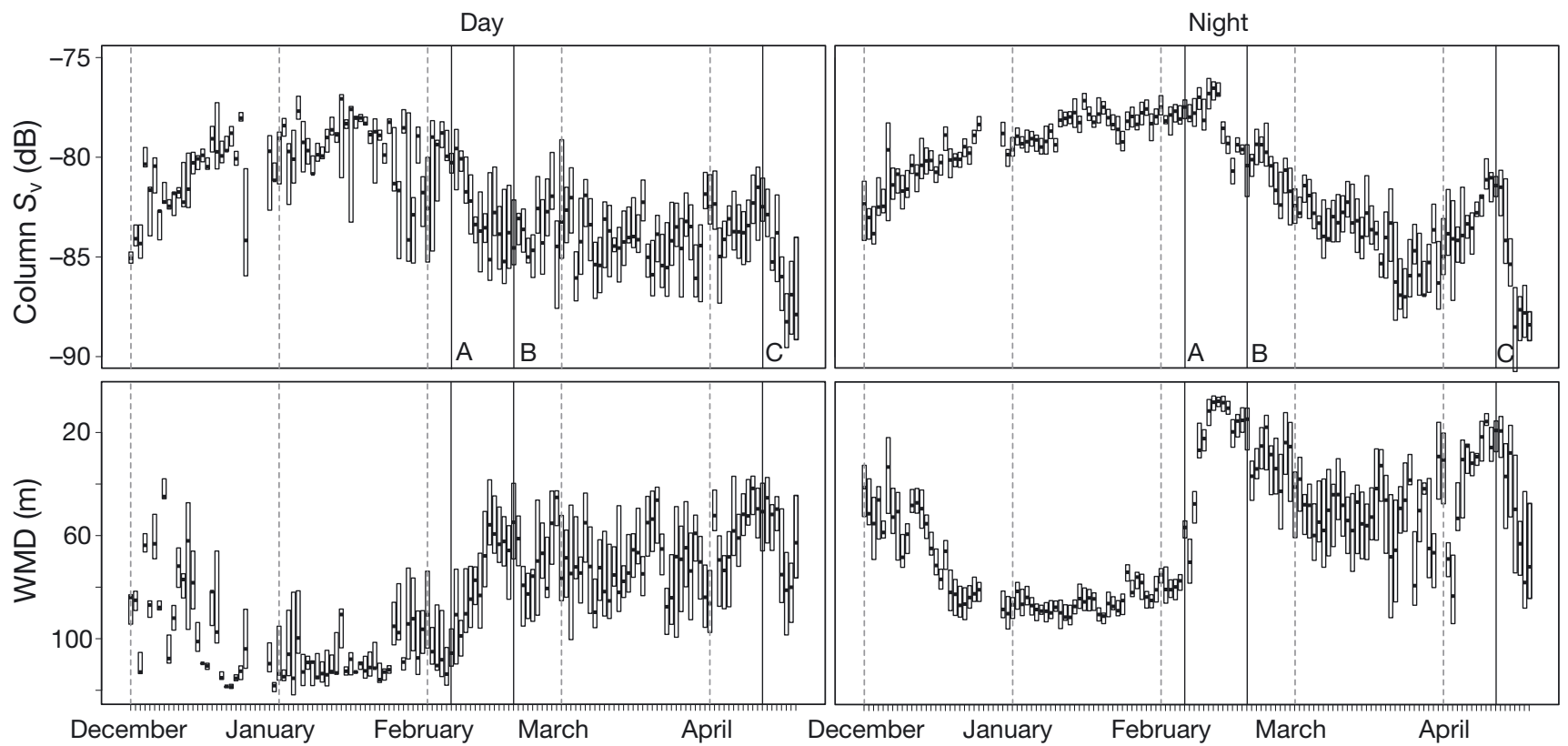

Fig. 2. Upper: boxplot showing daily values of total amount of acoustic biomass, as measured by mean volume backscattering strength $\left(S_{\mathrm{v}}\right)$ during the day (left) and at night (right). Lower: daily values of weighted mean depth (WMD) of sprat Sprattus sprattus during the day (left) and at night (right). Results are presented from 1 December to 19 April 2006; the medians are shown as horizontal lines, and the boxes are bound by 25th and 75th percentiles. The vertical dashed grey lines mark the beginning of every month, and the vertical solid black lines indicate the dates of changes in the physical environment: (A) 6 February, ice forms on fjord for the first time; (B) 19 February, water renewal; and (C) 12 April, disappearance of ice cover

ascended to form a scattering layer between $\sim 70$ and $120 \mathrm{~m}$ where they continued with a similar 'rise and sink' swimming behavior throughout the night (Fig. 3). The sprat descended with an average speed of $\sim 3.5 \mathrm{~cm} \mathrm{~s}^{-1}$ both day and night.

Another small part of the population schooled in mid-waters during the day. The schools dispersed within an hour after sunset, and while some individ- uals migrated towards the surface, others descended approximately $50 \mathrm{~m}$ to join the major part of the population, the 'rise and sink' swimmers during their ascent to mid-waters at dusk (Fig. 5). Further individuals moved between these groups at night (Fig. 4A). Echo traces of individuals leaving and descending from midwater schools during the daytime were also sporadically detected (not shown).

Table 1. Summary of behavior and abundance of the sprat Sprattus sprattus population throughout the winter (December 2005-April 2006) with changing environmental conditions. DVM: diel vertical migration

\begin{tabular}{|c|c|c|c|c|}
\hline Month & $\begin{array}{l}\text { Environmental } \\
\text { conditions }\end{array}$ & Sprat behavior (day) & Sprat behavior (night) & Abundance \\
\hline $\begin{array}{l}\text { December } \\
\text { and } \\
\text { January }\end{array}$ & $\begin{array}{l}\text { No ice } \\
30 \% \mathrm{O}_{2} \\
\text { saturation }\end{array}$ & $\begin{array}{l}\text { Majority: 'rise and sink' be- } \\
\text { havior in deep waters; minority: } \\
\text { schooling in mid-waters } \\
\text { Interactions between the two } \\
\text { behavioral modes are present }\end{array}$ & $\begin{array}{l}\text { DVM to mid-waters with 'rise } \\
\text { and sink' behavior throughout } \\
\text { the night }\end{array}$ & $\begin{array}{l}\text { Increasing } \\
\text { in December }\end{array}$ \\
\hline February & $\begin{array}{l}\text { Ice cover } \\
8 \text { February } \\
\text { Water exchange } \\
19 \text { February }\end{array}$ & $\begin{array}{l}\text { 'Rise and sink' swimming } \\
\text { is replaced by schooling in } \\
\text { mid-waters }\end{array}$ & $\begin{array}{l}\text { 'Rise and sink' swimming } \\
\text { is replaced by aggregating in } \\
\text { dense layers near the surface }\end{array}$ & $\begin{array}{l}\text { Declining after ice } \\
\text { coverage }\end{array}$ \\
\hline $\begin{array}{l}\text { March } \\
\text { and April }\end{array}$ & $\begin{array}{l}\text { Ice cover until } \\
14 \text { April } \\
60 \% \mathrm{O}_{2} \text { saturation }\end{array}$ & Schooling in mid-waters & $\begin{array}{l}\text { Scattering layers near } \\
\text { the surface }\end{array}$ & $\begin{array}{l}\text { Fluctuating } \\
\text { in March } \\
\text { Rapid decline } \\
\text { in April }\end{array}$ \\
\hline
\end{tabular}


A major change in the population behavior occurred in early February. In the course of $1 \mathrm{wk}$, sprat left the near-bottom habitat, abandoned their 'rise and sink' behavior and started schooling in mid waters during the day (Fig. 4B,C). The nocturnal distribution changed accordingly and a scattering layer of sprat was formed near the surface during night (Fig. 4B,C).

\section{Weighted mean depth}

The WMDs in December were highly variable during daytime (Fig. 2). The disparity decreased in January, and until the first week of February daytime mean depths were mainly concentrated between 90 and $110 \mathrm{~m}$ (Fig. 2). The night-time distribution deepened in the course of the first part of December, and was thereafter relatively stable at approximately 80 to $90 \mathrm{~m}$ (i.e. 10 to $30 \mathrm{~m}$ shallower than during the day) until the beginning of February (Fig. 2). A significant difference was found between day and night depths when comparing daily aver-
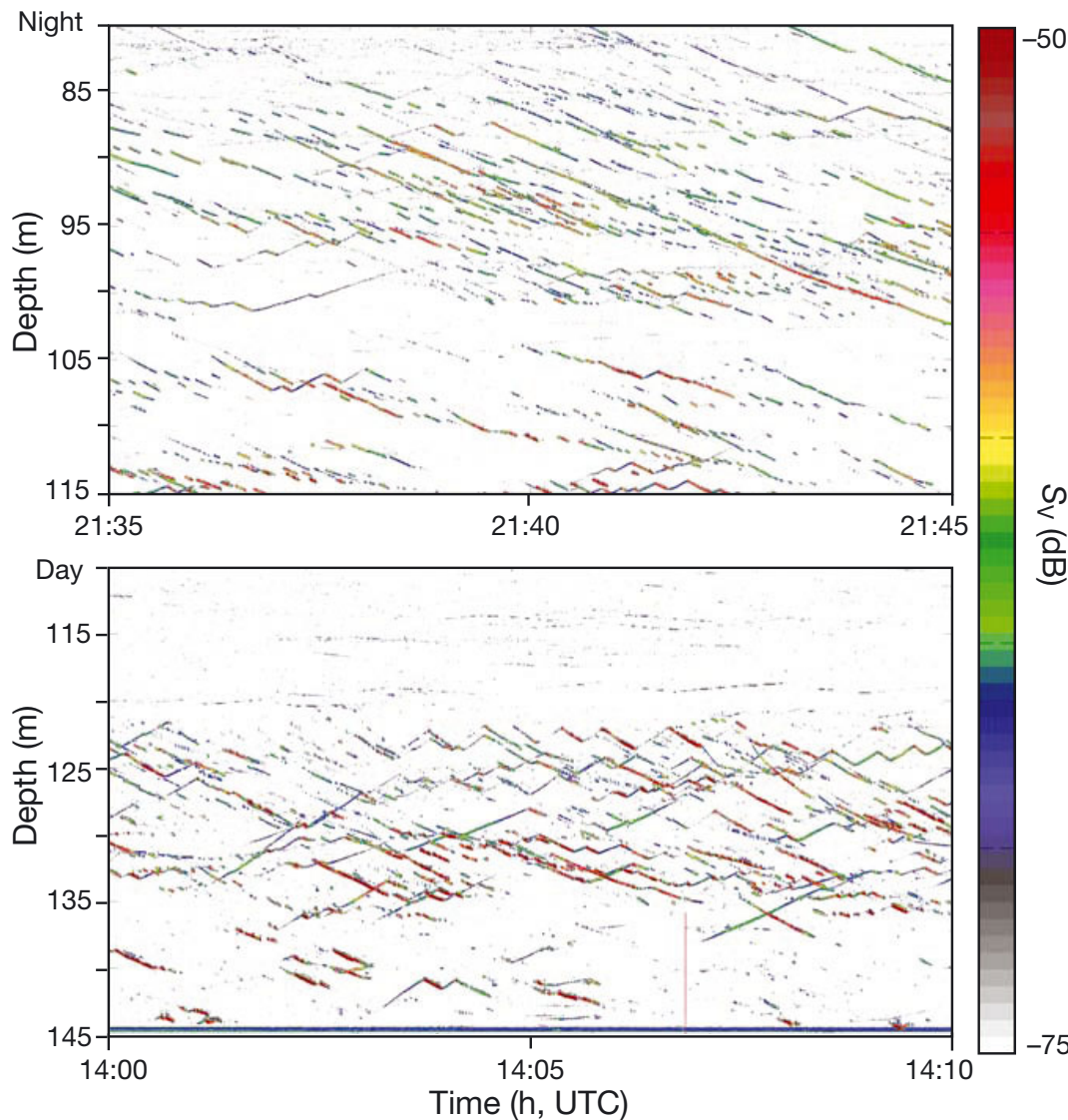

Fig. 3. Acoustic records from 2 January 2006 showing individual sprat Sprattus sprattus with a continuous 'rise and sink' behavior at night (upper) and during the day (lower) ages from December and January (Mann-Whitney $U$-test, $\mathrm{n}=58, \mathrm{p}<<0.01)$.

The WMDs became noticeably shallower both during the day and particularly at night during the course of 1 wk from the 6 February. Daily averages in the first week of February were significantly different than averages from the last week of February for both day and night values (Mann-Whitney U-test, $\mathrm{n}=14, \mathrm{p}<0.01)$. After 19 February, the WMDs intermittently deepened for a few days (Fig. 2). Throughout the rest of the period, the WMDs fluctuated between 40 and $80 \mathrm{~m}$ during the day and 30 to $60 \mathrm{~m}$ at night. Particularly strong fluctuations in depth were recorded in connection with heavy snowfall, which evidently altered the under-ice light conditions. One example is shown in Fig. 6.

\section{DISCUSSION}

This long-term acoustic study has provided continuous data on the distribution and swimming behavior of sprat throughout an entire winter and has unveiled information on individual behavior as well as apparent population responses to ice cover. The sprat accumulated in the Bunnefjorden overwintering habitat throughout the course of December, which follows the seasonal decline of prey availability in the Oslofjord (see Bagøien et al. 2000). The abundance of sprat in the overwintering habitat started declining after the fjord became ice covered, suggesting that $\propto$ the environment became less favora able. Abundance eventually decreased rapidly in April, likely reflecting the end of the overwintering period.

\section{Individual 'rise and sink' swimming}

The majority of the population was constantly swimming up and down during the first part of the winter. Such 'rise and sink' swimming behavior has previously been observed in overwintering sprat, but only at night (Kaartvedt et al. 2009). This behavior is not likely to be a search strategy because $85 \%$ of the stomachs in the depth range 50-150 m 


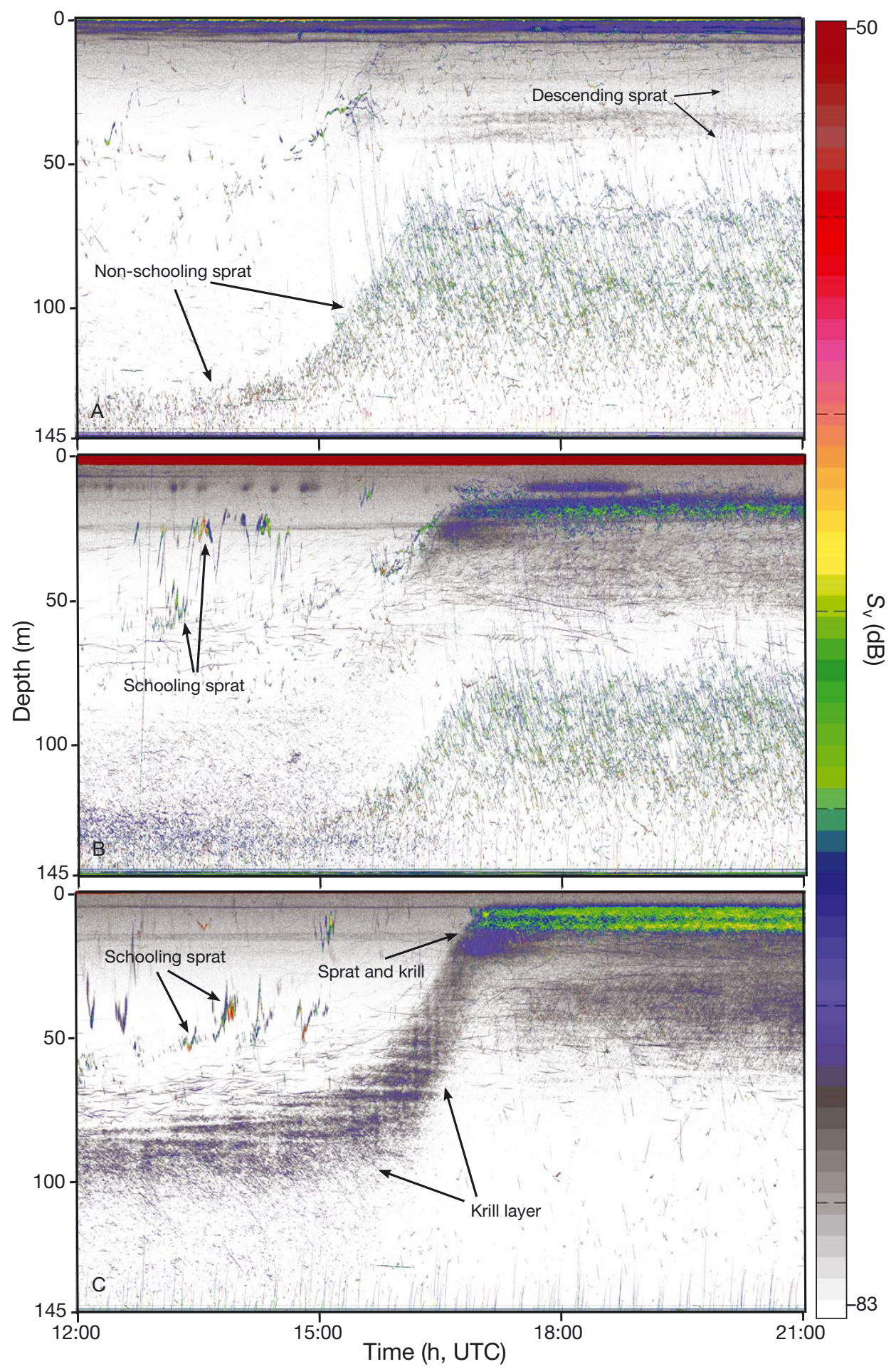

Fig. 4. Acoustic records showing the vertical distribution of sprat Sprattus sprattus in a $9 \mathrm{~h}$ period (12:00-21:00 h). Local time is UTC +1 h. (A) Echogram from 6 January 2006 (sunset at 14:31 h) showing that the majority of sprat are distributed in bottom waters during the day and up to $75 \mathrm{~m}$ depth at night; DVM is carried out in the lower half of the water column. (B) 5 February 2006 (sunset at 15:42 h). Two groups of sprat are present: one group of 'schooling' sprat in upper layers and one group of nonschooling sprat (individuals with 'rise and sink' swimming) in deeper water masses. (C) 14 February 2006 (sunset at 16:05 h). The majority of the sprat population are schooling in upper layers during the day and are distributed in dense layers close to the surface at night. The weaker backscattering of krill is seen as a blue layer below the schooling sprat. (The vertical lines that ascend up to $20 \mathrm{~m}$ from the bottom are acoustic backscatter ascribed to bubbles released from the transceiver box, caused by metal corrosion) 


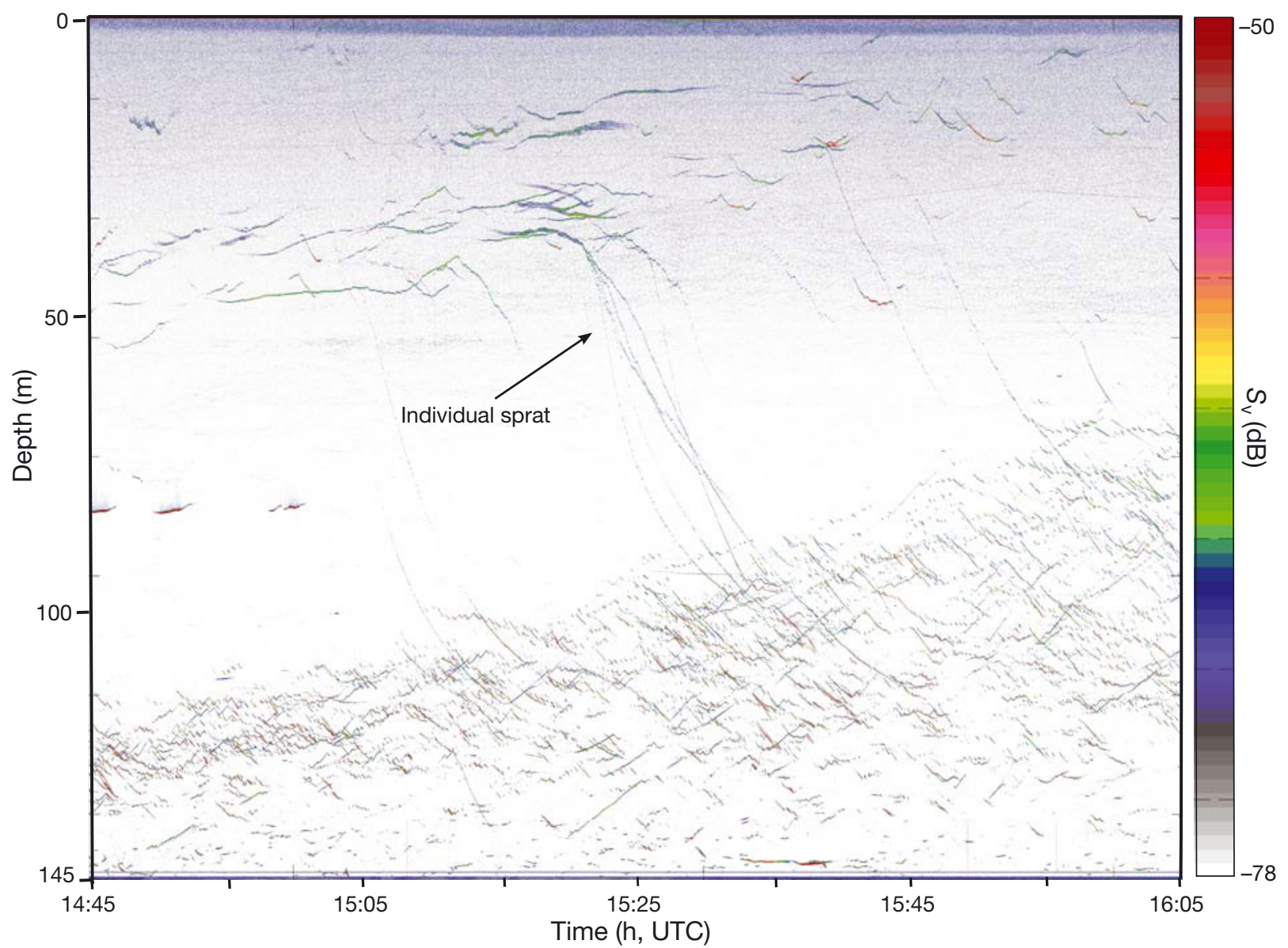

Fig. 5. Acoustic record from 9 January 2006 showing individual sprat Sprattus sprattus leaving mid-water schools subsequent to sunset, descending to join the concurrently ascending deeper group of sprat (sunset at 14:36 h). Local time is UTC $+1 \mathrm{~h}$

were empty during November-January. Rather, such swimming has been explained as a strategy for conserving energy in herring Clupea harengus (Huse \& Ona 1996) and sprat (Kaartvedt et al. 2009). The clupeids are likely to be negatively buoyant at depth because of compression of the physostome swim bladder (see also Nero et al. 2004), which is normally refilled by gulping air at the surface (Blaxter \& Batty 1984). There are, however, studies that indicate that the swimbladder of physostomes may have greater volume in deep waters than what is expected from Boyles law on compression of gases (Thorne \& Thomas 1990, Nero et al. 2004, Gong et al. 2010), tentatively explained by biochemical action from bacteria in the gut (Brawn 1962) or physiological secretion of gas from the swimbladder epithelium (Sundnes et al. 1958). In any case, to remain at the same depth, the 'rise and sink' swimming adds up to a noteworthy vertical distance covered during the course of a day (Kaartvedt et al. 2009), far exceeding that involved in DVM.

\section{DVM to mid-waters}

The sprat migrated from deep waters to midwater at night during the first part of the winter. Nocturnal ascent is commonly ascribed to feeding on more abundant prey in upper waters (Pearre 2003), but this does not seem to apply in the present case. Plankton concentrations rather increased towards the bottom as overwintering Calanus - the most prominent potential prey-this winter occurred in concentrations of $\sim 140 \mathrm{~m}^{-3}$ in near-bottom waters $(140-120 \mathrm{~m})$, but only $\sim 10 \mathrm{~m}^{-3}$ above $85 \mathrm{~m}$ (Brun 2007).

Kaartvedt et al. (2009) suggested that nocturnal ascent in hypoxic waters is favorable because of better oxygen conditions in upper waters, but we reject this explanation for DVM in the present case because the oxygen profile was homogenous from below $20 \mathrm{~m}$ during winter 2005-2006. Another possible explanation would be that the sprat migrated to shallower waters to gain energy savings (reduced 


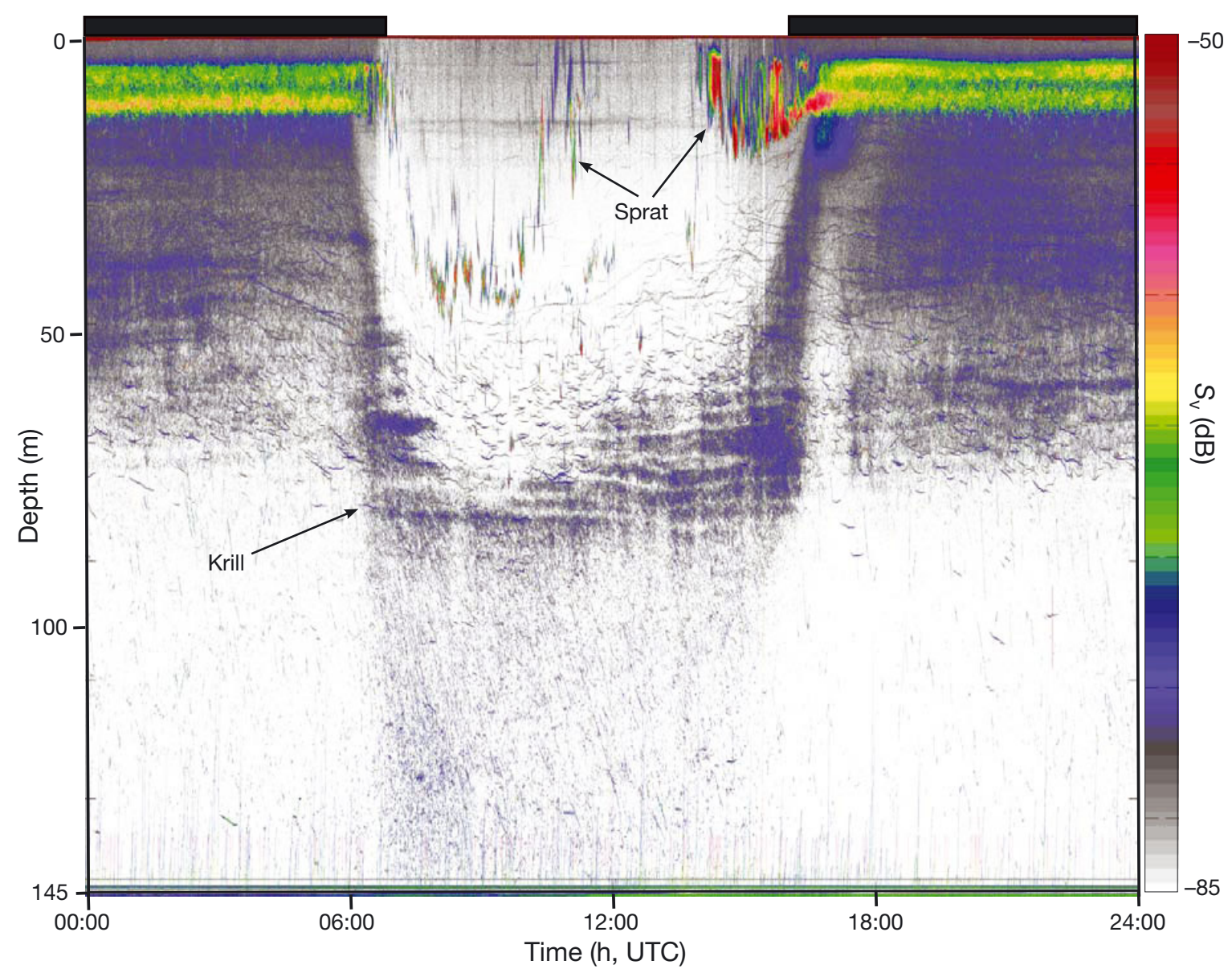

Fig. 6. Echogram from 15 February 2006 showing schools of sprat Sprattus sprattus and a layer of krill moving to shallower depths (at $\sim 10: 00 \mathrm{~h}$ ) due to heavy snowfall. The black lines at the top of the echogram indicate the hours of darkness

negative buoyancy by swimbladder expansion). However, our results do not support this hypothesis as the nocturnal sinking rates were similar to the diurnal rates.

DVMs are related to light in both plankton and fish (see reviews in Pearre 2003, Cohen \& Forward 2009, Ringelberg 2010). By applying an individual-based model to address DVM among jellyfish, Dupont et al. (2009) found that when individual migrators avoided light above a certain threshold, but also had a preference for (remaining above) very low light intensities, the model accounted for observed features of the DVM such as simultaneous synchronous and asynchronous migrations. To what extent fish may prefer to stay at light levels above a minimum level is not known, but migrations to mid-water at night, initiation of schooling in mid-water during daytime as the water became darker because of ice cover, as well as the sprat aggregating close to the surface at night after the ice covering would be in accordance with this explanation.

\section{Different behavioral modes}

The 'rise and sink' behavior was the dominant, but not the only behavior present in December and January, as a part of the population was schooling higher in the water column during daytime. Schools are generally interpreted in terms of predator avoidance, but schooling behavior may also benefit fish by reducing the energy cost of swimming caused by hydrodynamic advantages (Weihs 1973, Herskin \& Steffensen 1998) and increasing feeding (Magurran et al. 1985, Pitcher et al. 1988). The schools dispersed just after sunset and separated into individuals migrating towards the surface and individuals descending to deeper layers, the latter joining the deep component of the population. The average length of sprat increased slightly with depth, implying that the larger individuals prioritized predator avoidance in deep waters over schooling. However, examples of individuals switching between the 2 modes (e.g. leaving schools at mid-water and migrating as soli- 
tary individuals for more than $50 \mathrm{~m}$ during the day to join their conspecifics, with alternate behavior in their alternative habitat) suggest that the different modes were at least partly caused by variable individual internal states (e.g. fat storage, hunger, fear). Hensor et al. (2003) found that food-deprived killifish Fundulus diaphanus showed a reduced shoaling tendency compared with well-fed conspecifics, implying that the nutritional state of an individual can be decisive to its behavior. Corresponding differences in internal state might explain the co-occurring schooling and deeper 'rise and sink' swimming.

\section{Rapid alteration of vertical distribution and behavior}

The sudden change in both swimming behavior and vertical distribution in early February was the most conspicuous seasonal event in our data. Nearbottom 'rise and sink' swimming during the day was replaced by schooling behavior in mid-waters, and mid-water 'rise and sink' behavior at night was replaced by aggregating in dense layers near the surface.

Two major changes in the sprat overwintering habitat took place in February: the fjord froze over during the first week and there was a major water renewal during the third week. We ascribe the change in sprat behavior to the first event. It cooccurred closely with the fjord becoming ice covered, and preceded the subsequent water renewal by nearly 2 wk, given that the influx in more shallow water occurred at the same time as measured at depth. This indeed was indicated by acoustic results (not shown), which reflected a new type of echo at $\sim 100 \mathrm{~m}$ (due to either organisms that were transported with the influx of water or to turbulence; see Warren et al. 2003) on the afternoon of 19 February, the day the water renewal event was documented by the continuous temperature registrations nearbottom. Also, the influx of new, more oxygenated water affected other pelagic fauna at the exact date the water renewal was recorded, as reported by abrupt changes in the swimming behavior (increased swimming speed) of the krill Meganyctiphanes norvegica from 18 to 19 February (Klevjer \& Kaartvedt 2011). Although swimming activity of fish is highly affected by oxygen availability (Randall 1970, Bryan et al. 1990) and increased oxygen content may facilitate schooling among the sprat (Domenici et al. 2000, Domenici et al. 2002), this explanation seems less plausible for the behavioral change because of its the timing (as outlined above), and the oxygen conditions were nevertheless adequate for a part of the population to school earlier in the winter.

\section{Effect of ice covering}

The shallower distribution after 6 February may have been caused by means of a 'shadow effect' from the ice cover. This apparently made the sprat shift their antipredator strategy from hiding at depth to hiding in shallower schools. The amount of light penetrating the sea ice depends on the physical composition of the ice, its thickness and surface conditions; a layer of $25 \mathrm{~cm}$ snow can reduce transmittance through the ice by an order of magnitude (Maykut \& Grenfell 1975). Heavy snowfalls in the region of Oslo on 15 and 28 February caused an increase in snow depth by 11 and $25 \mathrm{~cm}$, respectively, and the schools responded by moving closer to the surface on these dates. Still, even with the shadow from the ice, light levels at mid-water depths likely would have been considerably higher than in the deep daytime habitat (50-70 m deeper) prior to ice formation. This is because light attenuation is exponential with depth, and at typical attenuation coefficients in the Oslofjord, one order of magnitude less incoming light at the surface would likely correspond to $<=15 \mathrm{~m}$ upward displacement of an isolume (authors' unpubl. results). The shift from individual swimming to schooling behavior is in accordance with this assumption, as fish tend to display increased schooling in more illuminated waters (Glass et al. 1986, Nilsson et al. 2003).

There is in general little knowledge about how ice conditions may impact the distribution and swimming behavior of fish, largely for logistic reasons (Lønne \& Gulliksen 1989). The arctic cod Boreogadus saida has a tendency to move underneath drifting ice (Crawford \& Jorgenson 1993), and Gradinger \& Bluhm (2004) found schools of fish resting in spaces under sea ice, suggesting that this is a strategy for reducing energy consumption and avoiding predators. Because sprat are physostome fish that may gulp air at the surface, it is possible that the permanent ice cover represented a constraint in that it inhibited access to atmospheric air. This would be in accordance with the decline in population abundance in the latter part of winter. However, how ice conditions impact the surfacing behavior, and habitat quality, of physostome fish awaits further examination. 
In conclusion, these results demonstrate that the overwintering strategy of sprat is dynamic, and that the sprat has a flexible behavioral repertoire. The strategy of the same population may change with changing environmental conditions, and may also differ between individuals in the population.

\section{LITERATURE CITED}

Bagøien E, Kaartvedt S, Øverås S (2000) Seasonal vertical migrations of Calanus spp. in Oslofjorden. Sarsia 85: 299-311

Balk H, Lindem T (2005) Sonar4 and Sonar5-Pro postprocessing systems (operation manual). University of Oslo, Oslo

Blaxter JHS, Batty RS (1984) The herring swimbladder: loss and gain of gas. J Mar Biol Assoc UK 64:441-459

Brawn VM (1962) Physical properties and hydrostatic function of the swimbladder of herring (Clupea harengus L.). J Fish Res Board Can 19:635-656

Brun H (2007) Vertical distribution and trophic interactions of krill, sprat and gadoids in the inner Oslofjord during winter. MS thesis, University of Oslo, Oslo

> Bryan JD, Kelsch SW, Neill WH (1990) The maximum power principle in behavioral thermoregulation by fishes. Trans Am Fish Soc 119:611-621

> Casini M, Cardinale M, Hjelm J (2006) Inter-annual variation in herring, Clupea harengus, and sprat, Sprattus sprattus, condition in the central Baltic Sea: What gives the tune? Oikos 112:638-650

Cohen JH, Forward RB (2009) Zooplankton diel vertical migration - a review of proximate control. Oceanogr Mar Biol Annu Rev 47:77-110

Crawford RE, Jorgenson JK (1993) Schooling behaviour of arctic cod, Boreogadus saida, in relation to drifting pack ice. Environ Biol Fishes 36:345-357

> Daskalov GM (2003) Long-term changes in fish abundance and environmental indices in the Black Sea. Mar Ecol Prog Ser 255:259-270

> Domenici P, Steffensen JF, Batty RS (2000) The effect of progressive hypoxia on swimming activity and schooling in Atlantic herring. J Fish Biol 57:1526-1538

> Domenici P, Ferrari RS, Steffensen JF, Batty RS (2002) The effect of progressive hypoxia on school structure and dynamics in Atlantic herring Clupea harengus. Proc Biol Sci 269:2103-2111

$>$ Dupont N, Klevjer TA, Kaartvedt S, Aksnes DL (2009) Diel vertical migration of the deep-water jellyfish Periphylla periphylla simulated as individual responses to absolute light intensity. Limnol Oceanogr 54:1765-1775

Engås A, Skeide R, West CW (1997) The 'MultiSampler': a system for remotely opening and closing multiple codends on a sampling trawl. Fish Res 29:295-298

Glass CW, Wardle CS, Mojsiewicz WR (1986) A light intensity threshold for schooling in the Atlantic mackerel, Scomber scombrus. J Fish Biol 29:71-81

Gong Z, Andrews M, Jagannathan S, Patel R, Jech JM, Makris NC, Ratilal P (2010) Low-frequency target strength and abundance of shoaling Atlantic herring (Clupea harengus) in the Gulf of Maine during the Ocean Acoustic Waveguide Remote Sensing 2006 Experiment. J Acoust Soc Am 127:104-123
Gradinger RR, Bluhm BA (2004) In-situ observations on the distribution and behavior of amphipods and Arctic cod (Boreogadus saida) under the sea ice of the High Arctic Canada Basin. Polar Biol 27:595-603

> Harvey CJ, Cox SP, Essington TE, Hansson S, Kitchell JF (2003) An ecosystem model of food web and fisheries interactions in the Baltic Sea. ICES J Mar Sci 60:939-950

> Hensor EMA, Godin JGJ, Hoare DJ, Krause J (2003) Effects of nutritional state on the shoaling tendency of banded killifish, Fundulus diaphanus, in the field. Anim Behav 65:663-669

> Herskin J, Steffensen JF (1998) Reduced tail beat frequency and oxygen consumption due to hydrodynamic interactions of schooling sea bass, Dicentrarchus labrax L. J Fish Biol 53:366-376

Hoag H (2003) Atlantic cod meet icy death. Nature 422:792

Hurst TP (2007) Causes and consequences of winter mortality in fishes. J Fish Biol 71:315-345

Huse I, Ona E (1996) Tilt angle distribution and swimming speed of overwintering Norwegian spring spawning herring. ICES J Mar Sci 53:863-873

> Huusko A, Greenberg L, Stickler M, Linnansaari T and others (2007) Life in the ice lane: the winter ecology of stream salmonids. River Res Appl 23:469-491

Kaartvedt S, Røstad A, Klevjer TA (2009) Sprat Sprattus sprattus can exploit low oxygen waters for overwintering. Mar Ecol Prog Ser 390:237-249

Klevjer TA, Kaartvedt S (2011) Krill (Meganyctiphanes norvegica) swim faster at night. Limnol Oceanogr 56: 765-774

Kynard B, Horgan M, Kieffer M, Seibel D (2000) Habitats used by shortnose sturgeon in two Massachusetts Rivers, with notes on estuarine Atlantic sturgeon: a hierarchical approach. Trans Am Fish Soc 129:487-503

Lønne OJ, Gulliksen B (1989) Size, age and diet of polar cod, Boreogadus saida (Lepechin 1773), in ice covered waters. Polar Biol 9:187-191

> Magurran AE, Oulton WJ, Pitcher TJ (1985) Vigilant behaviour and shoal size in minnows. Z Tierpsychol 67:167-178

> Maykut GA, Grenfell TC (1975) The spectral distribution of light beneath first-year sea ice in the Arctic ocean. Limnol Oceanogr 20:554-563

> Nero RW, Thompson CH, Jech JM (2004) In situ acoustic estimates of the swimbladder volume of Atlantic herring (Clupea harengus). ICES J Mar Sci 61:323-337

Nilsson LAF, Thygesen UH, Lundgren B, Nielsen BF, Nielsen JR, Beyer JE (2003) Vertical migration and dispersion of sprat (Sprattus sprattus) and herring (Clupea harengus) schools at dusk in the Baltic Sea. Aquat Living Resour 16:317-324

> Ojaveer E, Kalejs M (2005) The impact of climate change on the adaptation of marine fish in the Baltic Sea. ICES J Mar Sci 62:1492-1500

Pearre S Jr (2003) Eat and run? The hunger/satiation hypothesis in vertical migration: history, evidence and consequences. Biol Rev Camb Philos Soc 78:1-79

Pitcher TJ, Lang SH, Turner JR (1988) A risk-balancing trade-off between foraging rewards and predation hazard in shoaling fish. Behav Ecol Sociobiol 22:225-228

Randall DJ (1970) Gas exchange in fish. In: Hoar WS, Randall DJ (eds) Fish physiology, Vol 4. Academic Press, London, p 252-292

Riehle MD, Griffith JS (1993) Changes in habitat use and feeding chronology of juvenile rainbow trout (Oncorhynchus mykiss) in fall and the onset of winter in Silver 
Creek, Idaho. Can J Fish Aquat Sci 50:2119-2128

Ringelberg (2010) Diel vertical migration of zooplankton in lakes and oceans: causal explanations and adaptive significances. Springer, Dordrecht

Simmonds EJ, MacLennan DN (2005) Fisheries acoustics: theory and practice, 2nd edn. Blackwell Science, London

Simpson AC (1953) Some observations on the mortality of fish and the distribution of plankton in the southern North Sea during the cold winter, 1946-1947. J Cons Int Explor Mer 19:150-177

Stepputtis D, Hinrichsen HH, Böttcher U, Götze E, Mohrholz V (2011) An example of meso-scale hydrographic features in the central Baltic Sea and their influence on the

Editorial responsibility: Nicholas Tolimieri,

Seattle, Washington, USA distribution and vertical migration of sprat, Sprattus sprattus balticus (Schn.). Fish Oceanogr 20:82-88

Sundnes G, Enns T, Scholander PF (1958) Gas secretion in fishes lacking rete mirabile. J Exp Biol 35:671-676

Thorne RE, Thomas GL (1990) Acoustic observations of gas bubble release by Pacific herring (Clupea harengus pallasi). Can J Fish Aquat Sci 47:1920-1928

Warren JD, Stanton TK, Wiebe PH, Seim HE (2003) Inference of biological and physical parameters in an internal wave using multiple-frequency, acoustic-scattering data. ICES J Mar Sci 60:1033-1046

Weihs D (1973) Optimal fish cruising speed. Nature 245: 48-50

Submitted: December 6, 2011; Accepted: June 14, 2012 Proofs received from author(s): August 27, 2012 